\title{
Genetic diversity of indigenous guinea fowl (Numida meleagris) using microsatellite markers in northern Togo
}

\author{
Aïcha Edith Soara ${ }^{\text {Corresp., Equal first author, 1,2 }}$, Essodina Talaki Equal first author, 1, 3 , Guiguigbaza-Kossigan Dayo ${ }^{4}$, Isidore Houaga ${ }^{5}$, \\ Kokou Tona ${ }^{1,3}$, Mohammed Bakkali ${ }^{6}$ \\ ${ }^{1}$ Centre d'Excellence Régional sur les Sciences Aviaires, Université de Lomé, Lome, Togo \\ 2 Département Environnement et Forêts, Institut de l'Environnement et de Recherches Agricoles, Ouagadougou, Burkina Faso \\ 3 Ecole Supérieure d'Agronomie, Université de Lomé, Lome, Togo \\ 4 Institut du Sahel, Bamako, Mali \\ ${ }^{5}$ Centre International de Recherche-Développement sur l'Elevage en zone Subhumide, Bobo-Dioulasso, Burkina Faso \\ 6 Departamento de Genética, Facultad de Ciencias, Fuentenueva, Universidad de Granada, Granada, Spain \\ Corresponding Author: Aïcha Edith Soara \\ Email address: edith.soara@gmail.com
}

Indigenous guinea fowl is an important animal resource for improving rural household income. In order to provide molecular data for a sustainable management of this poultry resource, an assessment of the genetic diversity and phylogenic relationships was undertaken on seven guinea fowl phenotypes from two agroecological zones (Dry Savannah and Atakora) of Togo. Genotyping was carried out using 18 microsatellite markers on 94 individuals from Dry Savannah (59) and Atakora (35) zones. The results obtained showed a high genetic diversity, with 6 as an average alleles per locus and an observed heterozygosity of 0.512 . However, the $F_{\text {IS }}$ values varied from 0.047 (Lavender) to 0.257 (Albino), reflecting a deficit of heterozygotes, which suggests low to moderate inbreeding levels. The genetic distances between phenotypes are low, ranging from 0.0068 (Bonaparte-Pearl grey) to 0.1559 (Lavender-Albino), unlike the strong genetic identities that reflect a strong genetic similarity between the seven phenotypes of indigenous guinea fowl studied. These results indicate the existence of a single indigenous guinea fowl population, derived from three probable parental populations, with a high within population genetic diversity (phenotypic or agroecological zone). These results could be of use to conservation and improvement programs aiming at the maintenance and sustainable exploitation of this important socio-cultural and economic resource in Togo. 
1 Genetic diversity of indigenous guinea fowl (Numida meleagris)

2 using microsatellite markers in northern Togo

3

4

5

6

7

8

\section{Aïcha E. Soara ${ }^{1,2, *}$, Essodina Talaki ${ }^{1,3, *}$, Guiguigbaza-Kossigan Dayo ${ }^{4}$, Isidore Houaga ${ }^{5}$, Kokou Tona ${ }^{1,3}$ and Mohammed Bakkali ${ }^{6}$}

${ }^{1}$ Centre d'Excellence Régional sur les Sciences Aviaires, Université de Lomé, Lomé, Togo

${ }^{2}$ Département Environnement et Forêts, Institut de l'Environnement et de Recherches Agricoles, Ouagadougou, Burkina Faso

${ }^{3}$ Ecole Supérieure d'Agronomie, Université de Lomé, Lomé, Togo

${ }^{4}$ Institut du Sahel, Bamako, Mali

${ }^{5}$ Centre International de Recherche-Développement sur l'Elevage en zone Subhumide, BoboDioulasso, Burkina Faso

${ }^{6}$ Departamento de Genética, Facultad de Ciencias, Universidad de Granada, Fuentenueva, Granada, Spain

* These authors contributed equally to this work

Corresponding Author:

Aïcha E. Soara ${ }^{1,2}$

${ }^{1}$ Centre d'Excellence Régional sur les Sciences Aviaires, Université de Lomé, B.P. 1515 Lomé, Togo

${ }^{2}$ Département Environnement et Forêts, Institut de l'Environnement et de Recherches Agricoles, BP 7047 Ouagadougou, Burkina Faso

Email address: edith.soara@gmail.com

\section{ABSTRACT}

Indigenous guinea fowl is an important animal resource for improving rural household income. In order to provide molecular data for a sustainable management of this poultry resource, an assessment of the genetic diversity and phylogenic relationships was undertaken on seven guinea fowl phenotypes from two agroecological zones (Dry Savannah and Atakora) of Togo. Genotyping was carried out using 18 microsatellite markers on 94 individuals from Dry 
Savannah (59) and Atakora (35) zones. The results obtained showed a high genetic diversity, with 6 as an average alleles per locus and an observed heterozygosity of 0.512 . However, the $F_{\text {IS }}$ values varied from 0.047 (Lavender) to 0.257 (Albino), reflecting a deficit of heterozygotes, which suggests low to moderate inbreeding levels. The genetic distances between phenotypes are low, ranging from 0.0068 (Bonaparte-Pearl grey) to 0.1559 (Lavender-Albino), unlike the strong genetic identities that reflect a strong genetic similarity between the seven phenotypes of indigenous guinea fowl studied. These results indicate the existence of a single indigenous guinea fowl population, derived from three probable parental populations, with a high within population genetic diversity (phenotypic or agroecological zone). These results could be of use to conservation and improvement programs aiming at the maintenance and sustainable exploitation of this important socio-cultural and economic resource in Togo.

\section{INTRODUCTION}

Helmeted guinea fowl (Numida meleagris) belonging to the order Galliformes, domesticated in West-Africa, probably in Mali and Sudan (Vignal et al. 2019). Its production provides many services to farmers, particularly meat, eggs, serving as an important protein source for consumers and therefore play an indispensable role in food security for the people. Despite these products provided by indigenous guinea fowl, it is still conidered as a traditional village poultry. In Togo, indigenous guinea fowl farming is widespread, especially in the two northern agroecological zones where it is an important source of income for rural households (Lombo et al., 2018). The production of this poultry species is mainly practised in semi-intensive systems in which the birds are kept in a poultry house and have free access to a pasture area during the day thus constituting a randomly mating unselected population that constitute a huge treasure of variable genotypes (Yeasmin et al., 2003). Due to the harsh environmental conditions under which the indigenous guinea fowl is kept, they may contain important genes and alleles for their adaptation to particular environments (Osei-Amponsah et al., 2010). Recent awareness of the value of genetic resources has encouraged studies on the genetic diversity in domestic animal species. Studies were carried out on the genetic diversity and population structuring of indigenous guinea fowl in Sub-Saharan Africa (Kayang et al., 2010; Weimann et al., 2016; Traoré et al., 2018). However, no information is available on the genetic diversity and structure of indigenous guinea fowl in Togo despite their socio-economic importance. Phenotypic characterization showed a 
63

64

65

66

67

68

great diversity between guinea fowl of Dry Savannah and Atakora agroecological zones on the one hand and between the different phenotypes based on the plumage colours on the other hand (Soara et al., 2020). However, it did not allow the specific identification of breeds, strains or ecotypes. Yet, it is important to determine whether indigenous guinea fowl populations in these two agroecological zones of Togo represent unique populations for the development of effective conservation programs, as well as to assess their diversity at the molecular level in order to provide recommendations regarding their future management and conservation (Osei-Amponsah et al., 2010). The guinea fowl has four known loci that influence its plumage colour and all of these loci are autosomal with three being recessive and the fourth incompletely dominant. Color varieties have been developed around these four mutations and their various combinations (Ghigi, 1924, 1966; Somes Jr., 1996). In the current study, our objective was to evaluate the genetic variability in each plumage color phenotype identified by the phenotypic characterization of guinea fowl of Togo (Soara et al., 2020). The use of polymorphism of molecular markers such as microsatellite loci is a reliable way of assessing genetic diversity within and between populations (Hillel et al., 2003; Osei-Amponsah et al., 2010; FAO, 2011; Fotsa et al, 2011). Indeed, microsatellite loci are abundant, randomly distributed in the genome, highly polymorphic and show co-dominant inheritance (Hillel et al., 2003; Ocampo et al., 2016; Vieira et al., 2016). To date, only few specific markers have been developed for guinea fowl (Botchway et al., 2013). Fortunately, cross-species amplification of microsatellite loci has been reported within closely related avian species (Kayang et al., 2002; Nahashon et al., 2008). For instance, microsatellite markers developed in other avian species such as chicken and quail have been used to assess the genetic diversity of domestic and wild guinea fowl populations in Benin, Ghana, Sudan and Burkina Faso (Kayang et al., 2010; Weimann et al., 2016; Traoré et al., 2018). The present study takes advantage of the available microsatellite markers that have been proven to work in the guinea fowl species to characterized for the first time the indigenous guinea fowl populations of Togo. The aim of this study was to assess the genetic diversity and structure in the main colour plumage phenotypes and in the indigenous guinea fowl populations in two agroecological zones of the northern Togo. The information and data generated could be used for management, improvement and/or conservation strategies of guinea fowl in Togo. 
93 MATERIALS AND METHODS

94 Study areas

95 The study was conducted between March and July 2018 in the fourteen (14) prefectures of the

96 two agroecological zones (Dry Savannah and Atakora) in Northern Togo (Fig. 1). With about

$971,085,260$ guinea fowl in 2012 (64\% of national production), the Dry Savannah and Atakora are

98 the main zones of guinea fowl production in Togo (FAO 2015).

99 The north of Togo is located between $0^{\circ}$ and $1^{\circ}$ East longitude and $9^{\circ}$ and $11^{\circ}$ North latitude. It

100 is bounded to the North by the Republic of Burkina Faso, to the East by the Republic of Benin,

101 to the West by the Republic of Ghana and to the South by the Wet Savannah zone.

102 - The Dry Savannah zone, located in extreme North of Togo, is divided administratively

103 into eight prefectures: Cinkasse, Tone, Tandjouare, Kpendjal, Western Kpendjal, Oti,

104 South Oti, and Keran. It is a lowland area and covers an area of $10,573 \mathrm{~km} 2$. The human

105 population, mainly rural, was estimated to be 985,900 inhabitants in 2013 (INSEED, 2019), with a growth rate of 3.18 percent. The climate of this zone is Sudanese, characterised by $1,000-1,100 \mathrm{~mm}$ of annual rainfall and $28.5^{\circ} \mathrm{C}$ of annual average temperature. The average humidity level of the area is $56 \%$ (Amey et al., 2014). The main vegetation consists of savannah woodland dominated by Andropogon tectorum and Combretum molle and shrubby savannah dominated by Andropogon tectorum and Crotalaria graminicola (Démakou, 2009). Majority of the zone inhabitants are peasant and subsistent farmers.

- The Atakora zone includes six prefectures: Kozah, Bassar, Doufelgou, Dankpen, Binah and Assoli and covers about 9,742 km2. It is a mountains area with a sudano-guinean climate. The zone receives an average annual rainfall of $1,250 \mathrm{~mm}$ and a minimum and maximum temperature of $21^{\circ} \mathrm{C}$ and $34^{\circ} \mathrm{C}$, respectively. The average humidity level is $63 \%$ (Amey et al., 2014). The natural vegetation is made of up of sudanian savannah, opened and dry forests (Nabede et al., 2018). The human population, estimated of 711,500 inhabitants in 2013 (INSEED, 2019), is entirely agriculturists. 


\section{DNA sampling and extraction}

122 A total of 94 adult guinea fowl were sampled in 26 villages belonging to the 14 prefectures of the

123 two agroecological zones in northern Togo (Fig. 1). In each village, 1 to 7 guinea fowl

124 specimens were randomly selected. Thus, 59 birds were sampled from the Dry Savannah zone

125 and 35 from the Atakora zone. Approximately $1.5 \mathrm{~mL}$ of whole blood was collected from the

126 wing vein of each sampled bird using $21 \mathrm{G}$ vacutainer needles and $5 \mathrm{~mL}$ vacutainer tubes

127 containing ethylenediaminetetra-acetic acid (EDTA) as anticoagulant. The tubes were

128 transported under cold conditions to the laboratory and stored at $+4{ }^{\circ} \mathrm{C}$. DNA was extracted at the

129 International Center for Research and Development on Livestock in the Subhumid zone

130 (CIRDES/Centre International de Recherche-Développement sur l'Elevage en zone Subhumide)

131 according the PIFLOTOU method. This method allows the extraction of DNA from nucleated

132 red blood cells in birds. It consists of extracting DNA from $20 \mu \mathrm{L}$ of whole blood in $600 \mu \mathrm{L}$ of

133 lysis solution $(60 \mu \mathrm{L}$ of Tris $\mathrm{HCl}+120 \mu \mathrm{L}$ of EDTA $+150 \mu \mathrm{L}$ of $\mathrm{NaCl}+250 \mu \mathrm{L}$ of SDS +20

$134 \mu \mathrm{L}$ of Proteinase $\mathrm{K}$ ). After incubation step at $37^{\circ} \mathrm{C}$ overnight, $250 \mu \mathrm{L}$ of saturated $\mathrm{NaCl}$ (usually

135 cold) was added per sample and the mixture was centrifuged for 30 minutes at 14,000

136 revolutions per minute. The majority of the supernatant was carrefully transfered to a tube

137 containing $2 \mathrm{~mL}$ of absolute ethanol (usually cold). The samples were let stand at $+4^{\circ} \mathrm{C}$ about 1

138 hour to allow the DNA to fully precipitate. The clot of DNA fibres was collected and placed in a

139 sterile $2 \mathrm{~mL}$ tube containing $250 \mu \mathrm{L}$ of Tris EDTA (TE) and incubated at $37^{\circ} \mathrm{C}$ overnight. After

140 dissolution, the DNA was quantified by spectrophotometry. The purity and concentration of the

141 extracted DNA were measured using a 1000 NanoDrop Spectrophotometer. The tubes containing

142 the DNA were stored at $-20^{\circ} \mathrm{C}$ until the amplification and the genotyping assays.

143 PCR amplification and genotyping

144 A set of eighteen (18) microsatellite markers were chosen for this study: 6 microsatellite markers

145 (GUJ0084, GUJ0013, GUJ0001, GUJ0066, GUJ0059 and GUJ0086) developed by Kayang et al.

146 (2002) for guinea fowl, quails and hens; 10 microsatellite markers (GF75, GF12, GF43, GF5,

147 GF74, GF69, GF13, GF168, GF37 and GF30) developed by Botchway et al. (2013) for guinea

148 fowl and 02 microsatellite markers (MCW0069 and MCW0222) from the panel recommended

149 by the FAO for the study of diversity in hens. The microsatellite markers were grouped in four

150 optimised multiplexes (Table 1), and the 5 ' end of the forward primer sequence of each 
151 microsatellite was accordingly labelled with one of the four fluorochromes (FAM, VIC, NED or

152 PET). Multiplexed polymerase chain reactions (PCR) was performed in a final volume of $12 \mu \mathrm{L}$

153 containing $10 \mathrm{ng}$ DNA template, 20 pmol of each forward and reverse primer, 10x PCR buffer,

$15425 \mathrm{mM} \mathrm{MgCl}_{2}, 25 \mathrm{mM}$ dNTPs and $5 \mathrm{U}$ Taq DNA polymerase. The amplification protocol

155 involved an initial DNA denaturation step at $94^{\circ} \mathrm{C}$ for $15 \mathrm{~min}$ followed by 30 cycles of

156 denaturation at $94^{\circ} \mathrm{C}(30 \mathrm{~s})$, primer annealing at $55^{\circ} \mathrm{C}$ or $60^{\circ} \mathrm{C}(1 \mathrm{~min})$ according to optimal

157 temperature of the primers, extension at $72^{\circ} \mathrm{C}(1 \mathrm{~min})$ and a final extension at $72^{\circ} \mathrm{C}$ for $15 \mathrm{~min}$.

158 An automated thermal cycler Veriti TM 96-Well Thermal cycler, Applied Biosystems was used.

159 The amplified products generated by PCR were electrophoresed on an AB3500 automatic DNA

160 sequencer using 8 capillaries (Applied Biosystems) at the CIRDES genotyping platform in Bobo-

161 Dioulasso (Burkina Faso). The GeneMapper version 5.0 software (Applied Biosystems) was

162 used to analyse the microsatellite markers electrophoretic profiles and estimate the size of the

163 fragments (alleles at different loci) in base pairs.

\section{Statistical analysis}

165 The genotypes obtained were analysed in order to estimate the following polymorphism

166 parameters: the total number of alleles, the average number of alleles per locus in all

167 subpopulations, the allelic richness, the observed (Ho) and expected $(\mathrm{He})$ heterozygosities. The

168 factorial correspondence analysis (FCA), to visualise the differences between the studied

169 subpopulations, and the Wright's F-statistics F $_{\mathrm{IS}}, \mathrm{F}_{\mathrm{ST}}$ and $\mathrm{F}_{\mathrm{IT}}$ (Wright, 1951) proposed by Weir \&

170 Cockerham (1984) were performed using GENETIX 4.05 (Belkhir et al., 2004) and FSTAT

1712.9 .4 (Goudet, 2005) software. The number of effective alleles and the polymorphism

172 information content (PIC) for each locus were estimated using Molkin v.3.0 software (Gutierrez

173 et al., 2005). In addition, the unbiased measures of the pairwise genetic distance and genetic

174 identity of Nei (1978) of the subpopulations were calculated using POPGENE version 1.32 (Yeh

175 et al., 1999). In order to visualize the genetic relationships between phenotypes, the estimated

176 distances were used to construct a phylogenetic tree following the Neighbour-Joining method

177 using the PHYLIP software (Felsenstein, 1993). The genetic structuring of the population and

178 the assignment of individuals to K populations were evaluated using the STRUCTURE 2.3.4

179 software (Pritchard et al., 2000). The distribution a posteriori of each individual's probability

180 values was inferred using a Bayesian approach. As genotyping information for the assumed 
181 parent populations was not available, we hypothesised $\mathrm{K}$ unknown populations of parents (K

182

183

184

185

186

187

188

189

190

191

192

193

194

195

196

197

198

199

200

201

202

203

204

205

206

207

208

209

210

varying from 2 to 6 with 10 repeats for each K). The analysis was performed with a burn-in period of 50,000 iterations and 100,000 Markov Chain Monte Carlo (MCMC) based on the assumption of uncorrelated allele frequencies between parental populations and an admixture model. The optimal value of ' $\mathrm{K}$ ' determining the most likely number of genetic clusters was identified on the basis of $\Delta \mathrm{K}$, the second order rate of change of $\mathrm{LnP}(\mathrm{D})$ proposed by Evanno et al. (2005) using the Structure Harvester programme (http://taylor0.biology.ucla.edu/structureHarvester/) (Earl \& Vonholdt, 2012).

\section{RESULTS}

\section{Loci polymorphism and intra-population diversity}

All the 18 microsatellite loci selected for genotyping the populations studied were polymorphic. A total of 108 alleles were identified from the 94 animals genotyped with an average number of $6.0 \pm 5.1$ alleles per locus (Table 2). The number of alleles per locus in the total population varied from 2 for loci GF5 and GUJ0084 to 25 for locus GUJ0066. The effective number of alleles per locus averaged 2.92 \pm 1.06 , ranging from 1.34 (GUJ0001) to 6.14 (GUJ0066). Across the agroecological zones, the average number of alleles was 5.2 alleles while this number varied across phenotypes, Black pied phenotype had the lowest average number of alleles (2.8) and Royal purple phenotype the highest (4.7 alleles) (Table 3). Within phenotypes, the allelic richness (AR) varied from 2.7 for the Black pied phenotype to 3.2 for the Pearl grey phenotype. The number of effective alleles ranged from 2.1 (Black pied) to 3.1 (Pearl grey). Compared to agroecological zones, the allelic richness was 4.9 and 4.7 for the Atakora and Dry Savannah subpopulations, respectively. The polymorphism information content (PIC) ranged from 0.235 (GUJ0001) to 0.825 (GUJ0066) with an average value of $0.556 \pm 0.149$. Out of the 18 loci studied, only six (GF43, GUJ0001, GF5, GUJ0084, GF30 and GF75) had a PIC value less than 0.5 (Table 2)

Across all subpopulations, the observed heterozygosity (Ho) ranged from 0.203 (GUJ0001) to 0.816 (GF37), with an average of $0.512 \pm 0.154$, while the expected heterozygosity (He) varied from 0.226 (GUJ0001) to 0.811 (GUJ0066), with an average of $0.604 \pm 0.137$. With the exception of GUJ0084, GF12 and GF37, all the other loci showed a heterozygote deficit compared to the expected according to the Hardy-Weinberg equilibrium ( $\mathrm{Ho}<\mathrm{He}$ ) with $\mathrm{F}_{\mathrm{IS}}$

Peer) reviewing PDF | (2021:05:61791:2:0:NEW 13 Nov 2021) 
211 values significantly higher than zero (Table 2). The observed heterozygosity in the Dry Savannah

212 guinea fowl subpopulation (0.522) was higher than the value obtained in the Atakora

213 subpopulation (0.498). The Lavender phenotype had the highest values for observed (0.610) and

214 expected (0.638) heterozygosity (Table 3). Apart from the Lavender and Black-pea phenotypes,

215 all the other phenotypes showed a significant deficit in heterozygotes. The $\mathrm{F}_{\text {IS }}$ values suggest a

216 significant heterozygote deficit in all but the Lavender and Black pied phenotypes.

\section{Inter-population diversity}

218 Factorial Correspondence Analysis (FCA) showed a high degree of genetic similarity between

219 the seven guinea fowl phenotypes studied (Fig. 2A) and between the two subpopulations of the

220 agroecological zones studied (Fig. 2B).

221 The overall deficit of heterozygotes in the total population is reflected by $\mathrm{F}_{\text {IT }}$ values ranging from

$222-0.122$ (GF37) to 0.347 (GUJ0059) with an average value of 0.171 . The pairwise genetic

223 distances between the seven indigenous guinea fowl subpopulations ranged from 0.0068

224 (Bonaparte-Pearl grey) to 0.1559 (Albino-Lavender). These genetic distances were inversely

225 proportional to the genetic identities between pairs of subpopulations (Table 4). Between the two

226 agroecological zones, the genetic distance and genetic identity were 0.0266 and 0.9737 ,

227 respectively. The phylogenetic tree obtained from pairwise genetic distance of Nei (1978)

228 between subpopulations is presented in Figure 3. It shows a clade that groups the Pearl grey,

229 Albino, Bonaparte, Black pied and Royal purple phenotypes, while the Lavender and the Multi-

230 coloured phenotypes appeared in separated branches.

231 The most consistent gain in information was obtained with a number of clusters $\mathrm{K}=3$ (Fig. 4).

232 Among the three groups defined at $\mathrm{K}=3$, Cluster 1 consisted mostly (39\%) of individuals from

233 the Dry Savannah, Cluster 2 predominated individuals from Atakora (43\%) and Cluster 3

234 included $27 \%$ and $24 \%$ of individuals from the Dry Savannah and Atakora, respectively. This

235 structuring shows the same trend as the FCA results.

\section{DISCUSSION}

237 The aim of this study was to assess the diversity and genetic structure of the indigenous guinea

238 fowl population in northern Togo using seven phenotypes from two agroecological zones as

239 subpopulations. The present study is the first investigation on indigenous guinea fowl population 
240 in Togo using molecular markers. All loci were polymorphic with an average PIC value of 0.556 , 241 considered to reflect reasonably informative loci (Botstein et al., 1980). Indeed, based on the 242 classification suggested by these authors, 66.7\% (12/18) of the microsatellite markers used in 243 this work were highly informative (PIC>0.50), 27.8\% (5/18) were reasonably informative $244(0.25<\mathrm{PIC}<0.50)$ and 5.5\% (1/18) slightly informative $(\mathrm{PIC}<0.25)$. The use of a mixture of

245 highly variable and less variable microsatellites should reduce the risk of overestimating genetic 246 variability (Wimmers et al., 2000). The panel of 18 microsatellite markers used in the present 247 study is therefore suitable for a genetic evaluation of the indigenous guinea fowl populations in 248 Togo.

249 A total of 108 alleles were found for the 18 microsatellite loci studied, with an average number 250 of 6.0 alleles per locus. This value is similar to the findings of Traoré et al. (2018) in guinea fowl 251 populations in Burkina Faso, but lower than the number reported by Kayang et al. (2010) in 252 guinea fowl populations in Benin and Ghana (11 alleles per locus) and by Weimann et al. (2016) 253 in wild and domestic guinea fowl in Sudan (9.7 alleles per locus). GUJ0066 locus showed the 254 highest polymorphism in our study (25 alleles) as well as in those of Kayang et al. (2010) and 255 Weimann et al. (2016) with 28 alleles and 36 alleles, respectively. In addition to the historic, 256 environmental and biological differences between the studied populations, the differences 257 observed between these studies could also be explained by the microsatellite markers used for 258 genotyping and by the size of the studied samples. Indeed, the nature of loci used influences the 259 average number of alleles per locus, and the number of alleles observed in a given locus in a 260 population tends to increase with the size of the sample examined, which means that this 261 parameter must be taken into account in comparisons of genetic diversity between populations 262 (Ollivier \& Foulley, 2013). To avoid these biases, correction methods (rarefaction and 263 264 extrapolation) have been proposed (El Mousadik and Petit, 1996; Foulley \& Ollivier, 2006). The estimation of allelic richness (AR) in our study is based on the rarefaction correction method implemented in FSTAT sofware. In the set of loci used in our work, the observed (Ho) and expected $(\mathrm{He})$ heterozygosity of 0.512 and 0.604 , respectively, were high. The Albino phenotype 267 showed the lowest heterozygosities $(\mathrm{Ho}=0.447$ and $\mathrm{He}=0.584)$ values while the Lavender 268 phenotype showed the highest values $(\mathrm{Ho}=0.610$ and $\mathrm{He}=0.638)$ (Table 3$)$. Still, $\mathrm{He}$ was 269 higher than Ho in all the subpopulations. Similar results were found by Kayang et al. (2010), 270 Traoré et al. (2018) and Weimann et al. (2016) in guinea fowl populations of West Africa and 
271 Sudan, respectively. The higher overall rates of heterozygosity indicate a high genetic diversity,

272 which is consistent with the great phenotypic variability observed previously in the same

273 subpopulations (Soara et al., 2020). The great genetic diversity in indigenous guinea fowl in

274 northern Togo could be the result of the absence of selection for specific phenotype or

275 production traits and/or uncontrolled mating in the semi-intensive rearing system, which has as

276 consequence a continuous genes flow between populations, the conservation of a high number of

277 alleles, and a strong heterozygosity in the populations. However, an observed heterozygosity

278 lower than that expected under the Hardy-Weinberg equilibrium hypothesis reflects a deficit of

279 heterozygotes in the population that could be related to inbreeding or technical problems of

280 amplification generating the null alleles. All the subpopulations studied here showed

281 heterozygote deficit as also depicted by positive $\mathrm{F}_{\mathrm{IS}}$ value. The Wright's fixation indices $\left(\mathrm{F}_{\mathrm{IS}}=\right.$

$2820.169, \mathrm{~F}_{\mathrm{ST}}=0.012$ and $\left.\mathrm{F}_{\mathrm{IT}}=0.171\right)$ found in indigenous guinea fowl population of Togo were

283 low. Similar results were reported in indigenous guinea fowl from Benin, Burkina Faso, Ghana

284 and Sudan (Kayang et al., 2010; Weimann et al., 2016; Traoré et al., 2018). The low $\mathrm{F}_{\mathrm{ST}}$ value

285 (0.012) means that only $1.2 \%$ of the total genetic variability could be ascribed to differences

286 between subpopulations, suggesting a low sub-structuring of the studied population. The low

287 difference of the genetic variability between the studied phenotypes is corroborated by the low

288 genetic distances and the high values of genetic identity between phenotypes and between

289 agroecological zones.

290 Low values of genetic distances were also reported by Kayang et al. (2010) and Weimann et al.

291 (2016). A genetic diversity study of India guinea fowl using Random amplified polymorphic

292 DNA (RAPD) showed a very high and almost identical genetic similarity (0.97 - 0.99) between

293 Lavender, Pearl grey and White guinea fowl phenotypes (Sharma et al., 1998). Bawej et al.

294 (2012) reported the same observation between the White and the Pearl grey guinea fowl in

295 Poland. In our study, over the seven phenotypes, only the Lavender phenotype stood out slightly

296 from the others. These results indicates that there is a weak genetic variation between the

297 phenotypes (based on the feathers - plumage — colour) and between the two agroecological

298 zones studied. The observed low genetic differentiation could be attributed to the many years of

299 non-selective breeding (on the basis of feather colour) and to the uncontrolled movements of

300 birds between agroecological zones and between border countries, which promotes gene flow

301 (Sharma et al., 1998 ; Bawej et al., 2012 ; Weimann et al., 2016 ; Traoré et al., 2018). In 
302 addition, the microsatellite markers used in the present study are neutral markers and, therefore, 303 are not involved in the determinism of the expression of feather colouring genes. The Atakora 304 and Dry Savannah guinea fowl subpopulations are also genetically close (genetic identity of 305 0.9737) which could explain the low predominance observed in the three clusters identified by 306 the a posteriori grouping from the STRUCRURE software. It also appears that the indigenous 307 guinea fowl in northern Togo seem to come from three parental populations with some 308 individuals specific to the Dry savannah zone or to the Atakora zone and others with a very 309 heterogeneous genetic structure. It would be interesting to include in future studies, 310 subpopulations from other agroecological zones of Togo but also guinea fowl populations from

311 border countries such as Burkina Faso, Benin and Ghana. It would be also interesting to 312 investigate on the genes underlying colour variation, most notably EDNRB2, in order to 313 understand how these genes can affect a phenotype. EDNRB2 gene was selected as the most 314 likely candidate gene due to its functional importance in melanocyte development and would 315 explain various phenotypes found in domesticated animals (Vignal et al., 2019).

316 The results obtained in the current study could serve as baseline information to breeding 317 strategies for the improvement and conservation on domestic guinea fowl populations in Togo. 318 Because of the low or a lack of clear differentiation between guinea fowl population in the two 319 agroecological zones, the future improvement strategy or program will not need to consider the 320 different ecotypes. It is necessary that efforts will be made to improve the farming conditions 321 such as the control of habitat, diet and diseases. Any strategy or program needs also to take into

322 account the local community preferences, the different uses of the species (consumption, income 323 generation, socio-cultural roles,...).

Traditionally, indigenous guinea fowl classification is based on the colour of the plumage. The present study showed a low genetic structuring in the seven phenotypes of indigenous guinea fowl in northern Togo. It also showed a heterozygotes deficit in the overall population and in the subpopulations represented by the phenotypes. The traditional rearing system, which is particularly based on wandering, allows gene flow between subpopulations of the indigenous guinea fowl population of Togo and no specific isolated genetic group was identified among the 
332 phenotypes studied. Despite a low level of differentiation, the high heterozygosity rates obtained

333 show that there is an important reservoir of genetic diversity in the indigenous guinea fowl of

334 Togo. This study provides a good genetic basis for establishing genetic improvement and

335 conservation strategies for guinea fowl in Togo. The information generated here is useful for

336 setting up programs of selection, genetic improvement and adaptation to tropical environmental

337 conditions in the study area, as well as for a sustainable use of the indigenous guinea fowl of

338 Togo. Such strategies and programs should also involve the indigenous communities in order to

339 exploit their interesting endogenous knowledge and combine them with scientific knowledge for

340 a better exploitation and conservation of the valuable economic and food resource that the guinea

341 fowl is to the people of the studied area.

342 ACKNOWLEDGMENT

343 We express our gratitude to the Regional Excellence Center on Poultry Sciences (CERSA) of

344 University of Lome (Togo) and the World Bank Group. We also thank the staff of International

345 Center for Research and Development on Livestock in the Subhumid zone (CIRDES) in Bobo-

346 Dioulasso (Burkina Faso). This work also benefitted from the aid and help of the ERASMUS+

347 and CICODE programme and the University of Granada (Spain).

\section{REFERENCES}

350 Amey KB, Samah OD, Azouma YO, Neglo K, Kouto EY, Alokpa K. 2014. Réduction de la 351 sensation des malaises thermiques: détermination et cartographie des orientations préférentielles

352 des bâtiments au Togo. Journal de la Recherche Scientifique de l'Université de Lomé (Togo), 353 Série E, 16 (3): 185-198.

354 Bawej M, Kokoszynski D, Bernacki Z. 2012. Evaluation of Genetic Similarity between White 355 and Grey Varieties of Guinea Fowl (Numida meleagris). Journal of Central European

356 Agriculture, 13: 654-661 DOI: 10.5513/JCEA01/13.4.1106.

357 Belkhir K, Borsa P, Chikhi L, Raufaste N, Bonhomme F. 2004. Genetix 4.05, logiciel sous 358 Windows TM pour la génétique des populations. Laboratoire Génome, Populations, Interactions, 359 CNRS UMR 5000, Université de Montpellier II, Montpellier (France). https://kimura.univ360 montp2.fr/genetix/ (consulté le 22 Juin 2020). 
361 Botstein D, White RL, Skolnick M, Davis RW. 1980. Construction of a genetic linkage map in

362

363

364

365

366

367

368

369

370

371

372

373

374

375

376

377

378

379

380

381

382

383

384

385

386

387

man using restriction fragment length polymorphisms. American Journal of Human

Genetics, 32: 314-331.

Botchway PK, Adenyo C, Kayang BB, Hayano A, Inoue-Murayama M. 2013. Development of 31 polymorphic microsatellite markers for guinea fowl (Numida meleagris) using nextgeneration sequencing technology. Conservation Genetics Resources, 5, 1163-1165 DOI 10.1007/s12686-013-9991-8.

Demakou Y. 2009. Paysages végétaux, flore et dynamique des écosystèmes végétaux de la région des savanes au Nord-Togo. Thèse de doctorat, Université de Lomé, 210 p.

Earl DA, Vonholdt BM. 2012. STRUCTURE HARVESTER: a program for visualizing STRUCTURE output and implementing the Evanno method. Conservation of Genetic Resources, 4: 359-361.

El Mousadik A, Petit RJ. 1996. High level of genetic differentiation for allelic richness among populations of the argan tree (Argania spinosa L. Skeels) endemic to Morocco. Theoretical and Applied Genetics, 92: 832-836.

Evanno G, Regnaut S, Goudet J. 2005. Detecting the number of clusters of individuals using the software STRUCTURE: a simulation study. Molecular Ecology, 14: 2611-2620.

Food and Agriculture Organization (FAO). 2011. Molecular genetic characterization of animal genetic resources. FAO Animal Production and Health Guidelines. No. 9. Rome, 85p.

Food and Agriculture Organization (FAO). 2015. Secteur Avicole Togo. Revues nationales de l'élevage de la division de la production et de la santé animales de la FAO. No. 9. Rome.

Felsenstein J. 1993. PHYLIP: phylogeny inference package (version 3.5c). University of Washington, Seattle.

Fotsa JC, Poné Kamdem D, Bordas A, Tixier-Boichard M, Rognon X. 2011. Assessment of the genetic diversity of Cameroon indigenous chickens by the use of microsatellites. Livestock Research for Rural Development 23 (05), Volume 23, Article \#118. Retrieved May 15, 2020, from http://www.lrrd.org/lrrd23/5/fots23118.htm 
388 Foulley JL, Ollivier L. 2006. Diversité génétique et richesse allélique: concepts et application à 389 des races bovines. Journées Rencontres Recherches Ruminants, 13: 227-230.

390 Ghigi A. 1924. On the Inheritance of colour in the guinea fowl. Proceedings of the $2^{\text {nd }}$ World's 391 Poultry Congress, May 10-18, 1924. Barcelona, 18-19.

392 Ghigi A. 1966. The breeding of guinea fowl in Italy. Proceedings of the $13^{\text {th }}$ World's Poultry 393 Congress. Kiev; 137.

394

395

396

397 398

399

400

401

402

403

404

405

406

407

408

409

410

411

412

413

414

Goudet J. 2005. FSTAT Version 2.9.4. A Program to Estimate and Test Population Genetics Parameters. https://www2.unil.ch/popgen/softwares/fstat.htm (accessed June 22 2020).

Gutiérrez JP, Royo LJ, Álvarez I, Goyache F. 2005. MolKin v2.0: a computer program for genetic analysis of populations using molecular coancestry information. Journal of Heredity, 96: 718-721.

Hillel J, Groenen MAM, Tixier-Boichard M, Korol AB, David L, Kirzhner VM, Burke T, Barre-Dirie A, Crooijmans RPMA, Elo K, Feldman MW, Freidlin PJ, Mäki-Tanila A, Oortwijn M, Thomson P, Vignal A, Wimmers K, Weigend S. 2003. Biodiversity of 52 chicken populations assessed by microsatellite typing of DNA pools. Genetics Selection Evolution, 35: 533-557 DOI: 10.1051/gse:2003038.

Institut National de la Statistique et des Etudes Economiques et Démographiques (INSEED). 2019. Annuaire Statistique du Togo 2010 -2013. 280p.

\section{Kayang BB, Inoue-Murayama M, Hoshi T, Matsuo K, Takahashi H, Minezawa M,} Mizutani M, Ito S. 2002. Microsatellite loci in Japanese quail and cross-species amplification in chicken and guinea fowl. Genetics Selection Evolution, 34: 233-253 DOI: 10.1051/gse:2002006.

Kayang BB, Youssao I, Inoue E, Naazie A, Abe H, Ito S, Inoue-Murayama M. 2010. Genetic diversity of helmeted Guinea fowl (Numida meleagris) based on microsatellite analysis. Journal of Poultry Science, 47: 120-124 DOI: 10.2141/jpsa.009103.

Lombo Y, Tona K, Bonfoh B. 2018. Analysis of the technical and sanitary constraints of the traditional breeding of Guinea fowl in "Région des Savanes" of Northern Togo. Journal of Pharmacy and Pharmacology, 6: 77-87 DOI: 10.17265/2328-2150/2018.01.009. 
415 Nabede KJP, Atakpama W, Pereki H, Batawila K, Akpagana K. 2018. Plantes à usage

416 dermato-cosmétique de la région de la Kara au Togo. Revue Agrobiologia, 8 (2): 1009-1020

417 DOI: 10.13140/RG.2.2.11094.70725.

418 Nahashon SN, Amenyenu A, Harris C, Adefope N. 2008. Chicken and quail microsatellite 419 markers reveal polymorphisms in Guinea fowl. Journal of Poultry Science, 45: 249-254 DOI: $420 \quad 10.2141 / j p s a .45 .249$.

421 Nei M. 1978. Estimation of average heterozygosity and genetic distance from a small number of 422 individuals. Genetics 89 (3): 583-590.

423 Ocampo R, Cardona H, Martínez R. 2016. Genetic diversity of Colombian sheep by 424 microsatellite markers. Chilean Journal of Agricultural Research 76 (1): 40-47 DOI: 425 10.4067/S0718-58392016000100006.

426 Ollivier L, Foulley JL. 2013. Mesure et évolution de la diversité génétique des plantes cultivées 427 et des animaux domestiques: indicateurs de diversité génétique animale. Comptes Rendus de 428 l'Académie d'Agriculture, 99 (2): 31-41.

429 Osei-Amponsah R, Kayang BB, Naazie A, Osei YD, Youssao IAK, Yapi-Gnaoré VC, 430 Tixier-Boichard M, Rognon X. 2010. Genetic diversity of Forest and Savannah chicken 431 populations of Ghana as estimated by microsatellite markers. Animal Science Journal, 81: 297432303 DOI: 10.1111/j.1740-0929.2010.00749.x.

433 Pritchard JK, Stephens M, Rosenberg NA, Donnelly P. 2000. Association mapping in 434 structured populations. American Journal of Human Genetics, 67: 170-181.

435 Sharma D, Appa Rao KBC, Singh HP, Totey SM. 1998. Randomly amplified polymorphic 436 DNA (RAPD) for evaluating genetic relationships among varieties of guinea fowl. Genetic 437 Analysis: Biomolecular Engineering, 14: 125-128.

438 Soara AE, Talaki E, Dayo GK, Tona K. 2020. Morpho-biometric characterization of 439 indigenous guinea fowl (Numida meleagris) populations in Northern Togo. International Journal 440 of Poultry Science, 19 (9): 432-446 DOI: 10.3923/ijps.2020.432.446.

441 Somes Jr RG. 1996. Guinea fowl plumage color inheritance, with particular attention on the dun 442 color. The Journal of heredity, 87 (2): 138-142. 
443 Traoré FG, Bayala B, Gréma M, Dayo GK, Tapsoba ASR, Soudré A, Sanou M, Pichler R, 444 Yougbaré B, Kaboré M, Traoré A, Tamboura HH, Périasamy K. 2018. Diversité et structure 445 génétiques de six populations de pintades locales (Numida meleagris) du Burkina Faso. Journal 446 of Animal \& Plant Sciences, 38 (1): 6041-6056.

447 Vieira MLC, Santini L, Diniz AL, Munhoz C. 2016. Microsatellite markers: what they mean 448 and why they are so useful. Genetics and Molecular Biology, 39 (3): 312-328 DOI: DOI: 449 10.1590/1678-4685-GMB-2016-0027.

450 Vignal A, Boitard S, Thebault N, Dayo GK, Yapi-Gnaoré V, Youssao I, Berthouly-Salazar 451 C, Palinkasbodzsar N, Guemene D, Thibaud-Nissen F, Warren WC, Tixier-Boichard M, 452 Rognon X. 2019. A guinea fowl genome assembly provides new evidence on evolution 453 following domestication and selection in galliformes. Molecular Ecology Resources 19, 997 454 1014 DOI: 10.1111/1755-0998.13017.

455

456

457

458

459

460

461

462

463

464

465

466

467

468

469
Weimann C, Eltayeb NM, Brandt H, Yousif IAS, Abdel Hamid MM, Erhardt G. 2016.

Genetic diversity of domesticated and wild Sudanese Guinea Fowl (Numida meleagris) based on microsatellite markers. Archives Animal Breeding, 59: 59-64 DOI: 10.5194/aab-59-59-2016.

Weir BS, Cockerham C. 1984. Estimating $F$-statistics for the analysis of population structure. Evolution, 38: 1358-1370.

Wimmers K, Ponsuksili S, Hardge T, Valle-Zarate A, Mathur PK, Horst P. 2000. Genetic distinctness of African, Asian and South American local chickens. Animal Genetics, 31: 159165.

Wright S. 1951. The genetical structure of populations. Annals of Eugenics, 15: 323-354.

Yeasmin T, Howlider MAR, Ahammad MU. 2003. Effect of introgressing dwarf gene from Bangladeshi indigenous to exotic breeds on egg production. International Journal of Poultry Science, 2 (4): 264-266.

Yeh FC, Yang RC, Boyle TBJ, Ye ZH, Mao JX. 1999. POPGENE, version 1.32, the userfriendly software for population genetic analysis, Molecular Biology and Biotechnology Centre, University of Alberta, Canada. 
Figure 1

Map of Dry Savannah and Atakora agroecological zones in northern Togo with the locations of guinea fowl sampled.

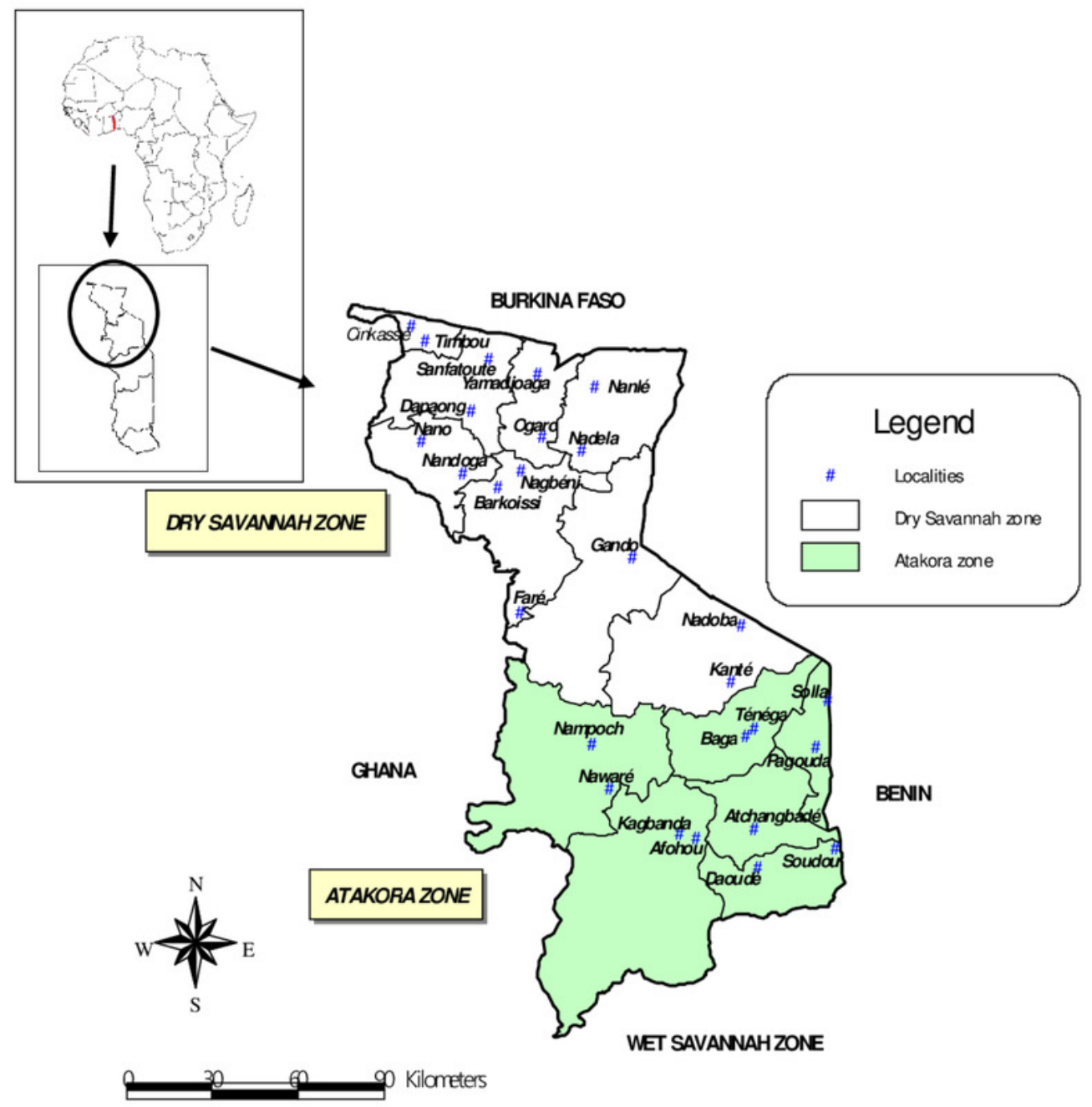

Auteur: TALAKI Essodina, ESA - CERSA / University of Lome, 2020 
Figure 2

The Factorial Correspondence Analysis (FCA) results. (A) The relationship between phenotypes. (B) The relations between guinea fowl populations of Atakora and Dry Savannah agroecological zones.

Yellow (Albino), Blue (Bonaparte), White (Pearl grey), Grey (Lavender), Purple (Black pied), Green (Multi-coloured), Blue-black (Royal Purple) 

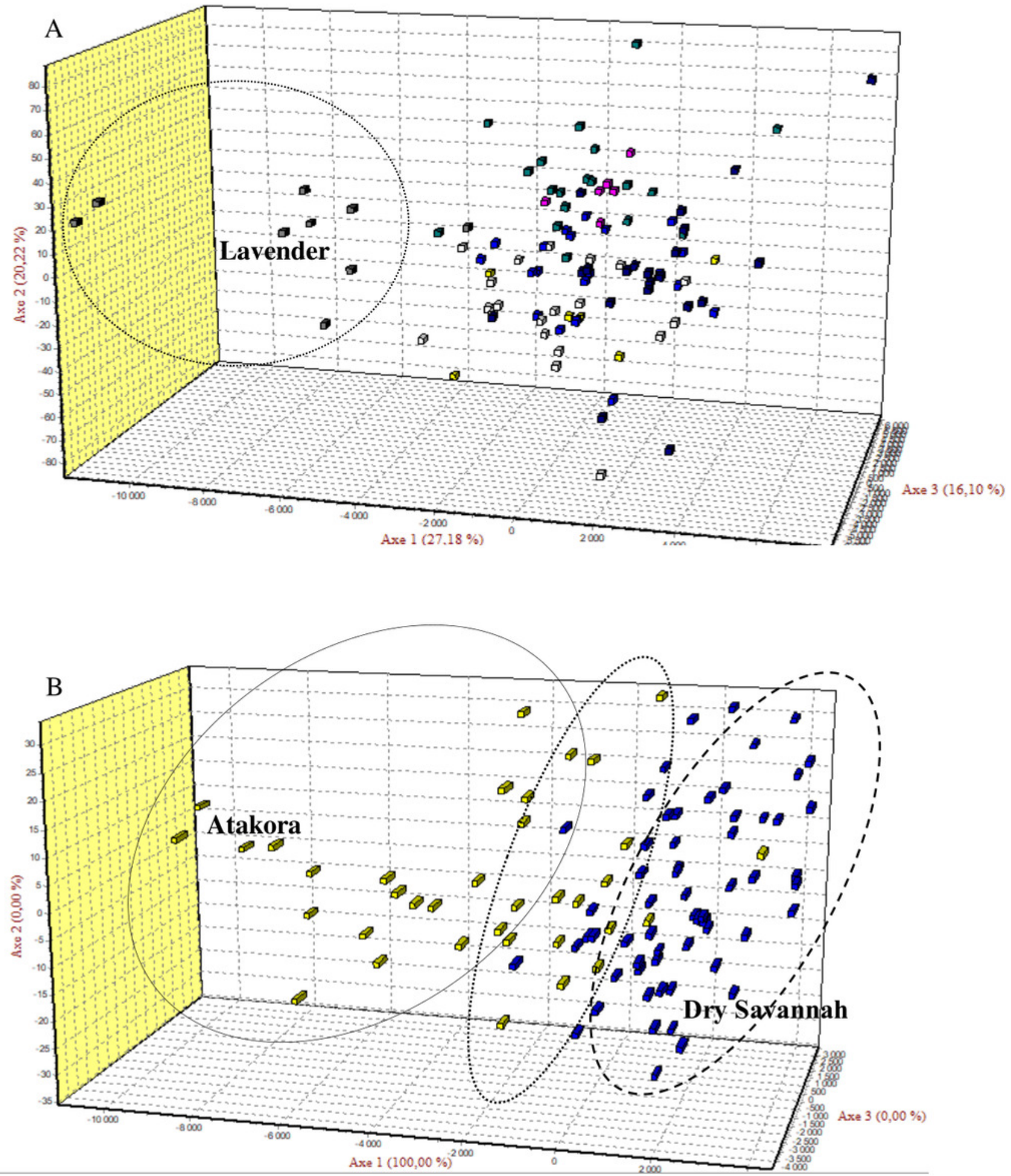
Figure 3

Phylogenetic tree representing Nei's genetic distance (Nei, 1978) between the seven phenotypes of indigenous guinea fowl in Togo.

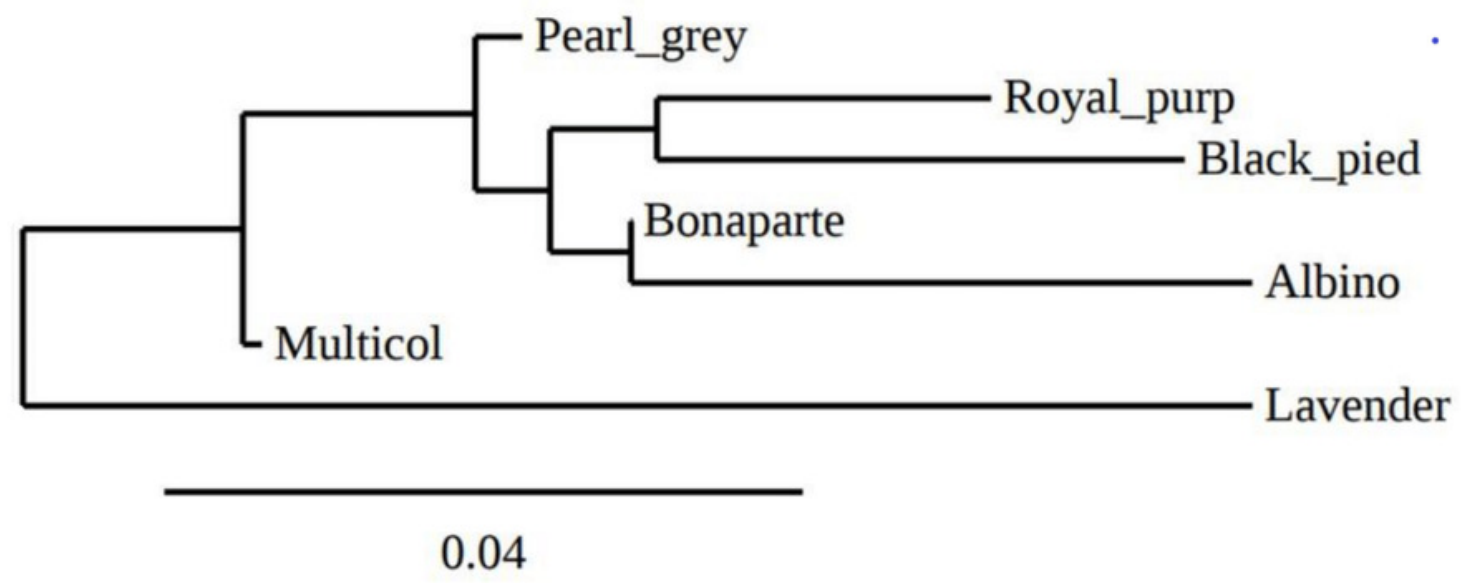




\section{Figure 4}

Clustering diagram based on STRUCTURE analysis of the two agroecological zones (Atakora, Dry Savannah for $\mathrm{K}=3$ ).

Each line representing a single individual and the shading representing the three population clusters Cluster 1: orange; Cluster 2: grey; Cluster 3: blue).

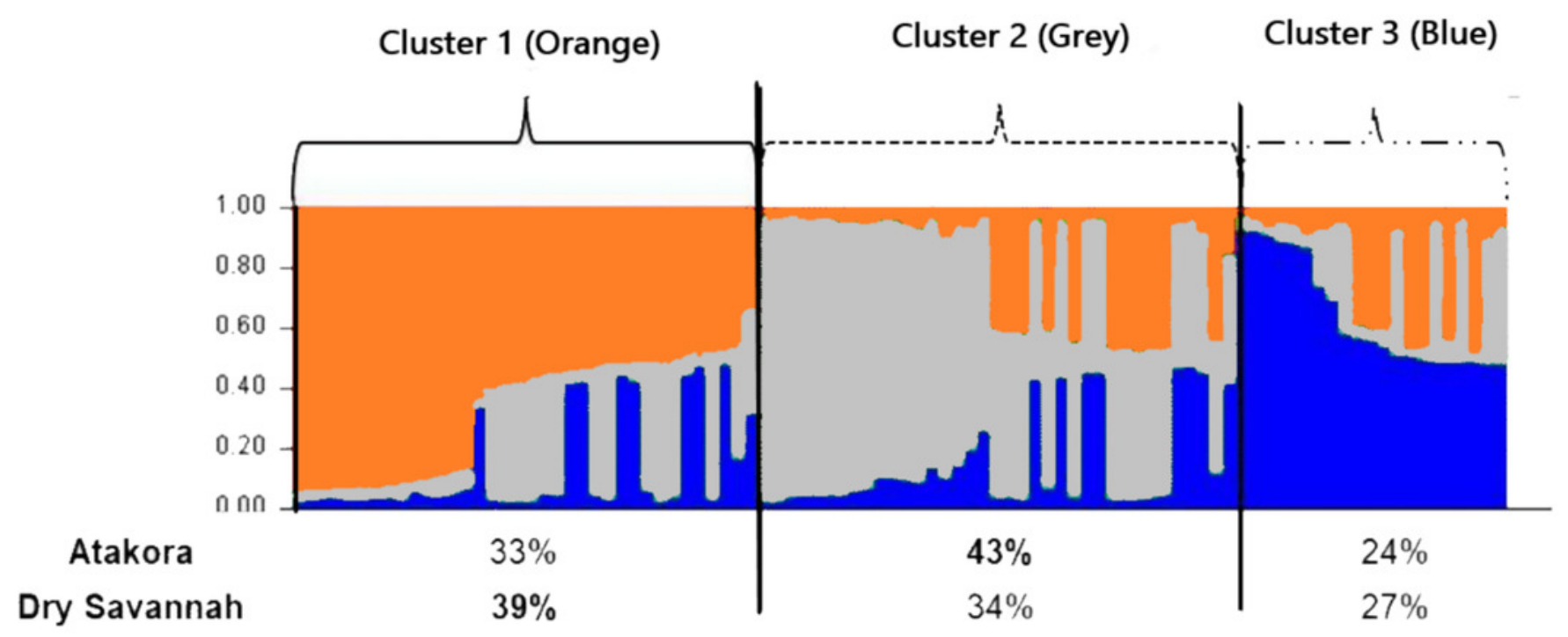




\section{Table $\mathbf{1}$ (on next page)}

Information on multiplexes and amplification temperatures. 
1 Table 1. Information on multiplexes and amplification temperatures

\begin{tabular}{|c|c|c|c|c|}
\hline Multiplexes & $\begin{array}{l}\text { Amplification } \\
\text { temperature }\left({ }^{\circ} \mathrm{C}\right)\end{array}$ & Loci & $\begin{array}{l}\text { Allele Size } \\
\text { (bp) }\end{array}$ & Fluorochrome \\
\hline \multirow[t]{4}{*}{ Multiplex 1} & 55 & GF43 & $111-117$ & VIC \\
\hline & & GUJ001 & $222-226$ & VIC \\
\hline & & GUJ0059 & $211-231$ & NED \\
\hline & & GUJ0066 & $161-255$ & PET \\
\hline \multirow[t]{5}{*}{ Multiplex 2} & 55 & GF13 & $114-136$ & FAM \\
\hline & & GF5 & $165-167$ & VIC \\
\hline & & GUJ0084 & $165-167$ & NED \\
\hline & & GF30 & $192-202$ & NED \\
\hline & & GF75 & $207-217$ & PET \\
\hline \multirow[t]{6}{*}{ Multiplex 3} & 60 & GF168 & $214-230$ & FAM \\
\hline & & GF12 & $100-110$ & FAM \\
\hline & & GUJ0013 & $134-150$ & FAM \\
\hline & & GF37 & $206-230$ & VIC \\
\hline & & GUJ0086 & $205-213$ & NED \\
\hline & & MCW0222 & $214-230$ & PET \\
\hline \multirow[t]{3}{*}{ Multiplex 4} & 60 & GF74 & $208-214$ & FAM \\
\hline & & GF69 & $182-200$ & VIC \\
\hline & & MCW0069 & $182-200$ & PET \\
\hline
\end{tabular}




\section{Table 2 (on next page)}

Number of alleles (Na), allelic richness (AR), effective number of alleles (Ae), observed heterozygosity $(\mathrm{Ho})$, expected heterozygosity $(\mathrm{He})$, polymorphism information content (PIC) and Wright's statistical $F\left(F_{I T}, F_{S T}\right.$ and $\left.F_{I S}\right)$ 
1 Table 2. Number of alleles (Na), allelic richness (AR), effective number of alleles (Ae), observed heterozygosity (Ho), expected

2 heterozygosity (He), polymorphism information content (PIC) and Wright's statistical F ( $\mathrm{F}_{\mathrm{IT}}, \mathrm{F}_{\mathrm{ST}}$ and $\left.\mathrm{F}_{\mathrm{IS}}\right)$ of the Atakora and Dry

\begin{tabular}{|c|c|c|c|c|c|c|c|c|c|}
\hline Loci & $\mathrm{Na}$ & AR & $\mathrm{Ae}$ & Ho & $\mathrm{He}$ & $\mathrm{PIC}$ & $\mathrm{F}_{\mathrm{IT}}$ & $\mathrm{F}_{\mathrm{ST}}$ & $\mathrm{F}_{\text {IS }}$ \\
\hline GF43 & 4 & 2.8 & 2.14 & 0.439 & 0.489 & 0.487 & 0.202 & 0.042 & 0.167 \\
\hline GUJ0001 & 3 & 1.9 & 1.34 & 0.203 & 0.266 & 0.235 & 0.184 & 0.027 & 0.161 \\
\hline GUJ0059 & 7 & 3.9 & 3.70 & 0.390 & 0.662 & 0.696 & 0.347 & 0.037 & 0.322 \\
\hline GUJ0066 & 25 & 5.3 & 6.14 & 0.540 & 0.811 & 0.825 & 0.323 & 0.009 & 0.317 \\
\hline GF13 & 7 & 3.6 & 3.40 & 0.502 & 0.655 & 0.663 & 0.258 & 0.026 & 0.238 \\
\hline GF5 & 2 & 2.0 & 1.88 & 0.447 & 0.452 & 0.358 & 0.059 & 0.000 & 0.070 \\
\hline GUJ0084 & 2 & 2.0 & 1.87 & 0.470 & 0.447 & 0.356 & -0.014 & 0.001 & -0.015 \\
\hline GF30 & 3 & 2.1 & 1.97 & 0.308 & 0.454 & 0.386 & 0.329 & 0.022 & 0.314 \\
\hline GF75 & 4 & 2.6 & 2.27 & 0.472 & 0.576 & 0.474 & 0.205 & 0.000 & 0.223 \\
\hline GF168 & 4 & 3.2 & 3.17 & 0.663 & 0.703 & 0.621 & 0.064 & 0.000 & 0.088 \\
\hline GF12 & 8 & 4.0 & 3.56 & 0.732 & 0.727 & 0.691 & 0.037 & 0.000 & 0.041 \\
\hline GUJ0013 & 4 & 3.1 & 3.15 & 0.663 & 0.702 & 0.618 & 0.062 & 0.000 & 0.084 \\
\hline GF37 & 7 & 3.6 & 3.61 & 0.816 & 0.740 & 0.673 & -0.122 & 0.000 & -0.106 \\
\hline GUJ0086 & 5 & 3.0 & 2.92 & 0.548 & 0.651 & 0.589 & 0.227 & 0.000 & 0.229 \\
\hline MCW0222 & 5 & 3.2 & 3.23 & 0.678 & 0.707 & 0.630 & 0.042 & 0.000 & 0.064 \\
\hline GF69 & 7 & 3.2 & 2.84 & 0.502 & 0.644 & 0.592 & 0.277 & 0.015 & 0.266 \\
\hline GF74 & 4 & 2.8 & 2.38 & 0.366 & 0.538 & 0.515 & 0.300 & 0.000 & 0.300 \\
\hline MCW0069 & 7 & 3.3 & 2.92 & 0.487 & 0.646 & 0.599 & 0.301 & 0.031 & 0.279 \\
\hline Average & 6.00 & 3.08 & 2.92 & 0.512 & 0.604 & 0.556 & 0.171 & 0.012 & 0.169 \\
\hline Standard deviation & 5.10 & 0.85 & 1.06 & 0.154 & 0.137 & 0.149 & 0.139 & 0.015 & 0.128 \\
\hline
\end{tabular}




\section{Table 3 (on next page)}

Average number of alleles ( $\mathrm{Na}$ ), allelic richness (AR), effective number of alleles (Ae), observed heterozygosity ( $\mathrm{Ho})$, expected heterozygosity $(\mathrm{He})$ and deviation from panmixia $\left(F_{1 S}\right)$ of the different populations 
1 Table 3. Average number of alleles (Na), allelic richness (AR), effective number of alleles (Ae), 2 observed heterozygosity ( $\mathrm{Ho})$, expected heterozygosity $(\mathrm{He})$ and deviation from panmixia $\left(\mathrm{F}_{\mathrm{IS}}\right)$

\begin{tabular}{llllllll}
\hline Population & $\mathrm{N}$ & $\mathrm{Na}$ & $\mathrm{AR}$ & $\mathrm{Ae}$ & $\mathrm{Ho}$ & $\mathrm{He}$ & $\mathrm{F}_{\mathrm{IS}}$ \\
\hline Phenotypes & & & & & & & \\
Albino & 5 & 3.2 & 3.0 & 2.6 & 0.447 & 0.584 & $0.257^{*}$ \\
Bonaparte & 19 & 4.3 & 3.0 & 2.7 & 0.496 & 0.606 & $0.185^{*}$ \\
Pearl grey & 19 & 4.6 & 3.2 & 3.1 & 0.521 & 0.633 & $0.181^{*}$ \\
Lavender & 8 & 3.6 & 3.1 & 2.7 & 0.610 & 0.638 & 0.047 \\
Black pied & 5 & 2.8 & 2.7 & 2.1 & 0.500 & 0.537 & 0.077 \\
Multi-coloured & 18 & 4.3 & 3.0 & 2.7 & 0.499 & 0.616 & $0.196^{*}$ \\
Royal purple & 20 & 4.7 & 3.1 & 2.8 & 0.514 & 0.617 & $0.170^{*}$
\end{tabular}

\section{Agroecological zones}

$\begin{array}{llllllll}\text { Atakora } & 35 & 5.17 & 4.9 & 3.24 & 0.498 & 0.619 & 0.199 \\ \text { Dry Savannah } & 59 & 5.22 & 4.7 & 3.05 & 0.522 & 0.614 & 0.150\end{array}$

3 of the different populations

$4 * p<0.05$

5 
Table 4 (on next page)

Unbiased measures of genetic identity (above matrix) and genetic distances (below matrix) according to Nei (1978) between the seven phenotypes of indigenous guinea fowl in Togo (The high values are in Bold and the small values in italics and underlined). 
1 Table 4. Unbiased measures of genetic identity (above matrix) and genetic distances (below 2 matrix) according to Nei (1978) between the seven phenotypes of indigenous guinea fowl in 3 Togo (The high values are in Bold and the small values in italics and underlined)

4

\begin{tabular}{llllllll}
\hline & Albino & Bonaparte & $\begin{array}{l}\text { Pearl } \\
\text { grey }\end{array}$ & Lavender & $\begin{array}{l}\text { Black } \\
\text { pied }\end{array}$ & $\begin{array}{l}\text { Multi- } \\
\text { coloured }\end{array}$ & $\begin{array}{l}\text { Royal } \\
\text { purple }\end{array}$ \\
\hline Albino & - & 0.9659 & 0.9492 & $\underline{0.8557}$ & 0.9244 & 0.9395 & 0.9271 \\
Bonaparte & 0.0346 & - & $\mathbf{0 . 9 9 3 2}$ & 0.8903 & 0.9581 & 0.9805 & 0.9736 \\
Pearl grey & 0.0521 & $\underline{0.0068}$ & - & 0.9109 & 0.9464 & 0.9670 & 0.9718 \\
Lavender & $\mathbf{0 . 1 5 5 9}$ & 0.1162 & 0.0933 & - & 0.8566 & 0.9125 & 0.8688 \\
Black pied & 0.0786 & 0.0428 & 0.0550 & 0.1548 & - & 0.9565 & 0.9492 \\
Multi-coloured & 0.0624 & 0.0197 & 0.0335 & 0.0916 & 0.0445 & - & 0.9492 \\
Royal purple & 0.0757 & 0.0267 & 0.0286 & 0.1406 & 0.0536 & 0.0522 & -
\end{tabular}

5 